\title{
Malnutrition and Body Composition in Urban and Rural Schoolchildren: A Cross-sectional Study in San Rafael, Mendoza (Argentina)
}

\author{
MARIELA GARRAZA, ${ }^{1 *}$ MARÍA F. CESANI, ${ }^{1}$ GRACIELA T. NAVONE, ${ }^{2}$ AND EVELIA E. OYHENART ${ }^{1,3}$ \\ ${ }^{1}$ IGEVET-Instituto de Genética Veterinaria "Ing. Fernando Noel Dulout" (UNLP-CONICET La Plata), Facultad de Ciencias Veterinarias \\ UNLP, La Plata, Argentina \\ ${ }^{2}$ CEPAVE-Centro de Estudios Parasitológicos y de Vectores (UNLP-CONICET La Plata), La Plata, Argentina \\ ${ }^{3}$ Cátedra de Antropología Biológica IV. Facultad de Ciencias Naturales y Museo, UNLP, La Plata, Argentina
}

Objectives: The aim of the present study was to analyze the nutritional status and body composition of children from San Rafael, Mendoza, avoiding urban and rural categorization by generating subpopulations as a function of their socio-environmental characteristics.

Methods: A cross-sectional study was performed in 3,596 schoolchildren from 4.0 to 13.9 years of age. Body weight, height, upper arm circumference, and triceps skinfold were measured. Body mass index, total muscle, and fat areas of the arm were calculated. To estimate nutritional status and body composition, the NHANES III reference was used. The socio-environmental variables were surveyed using a structured questionnaire. These variables were processed by categorical principal-component analysis (catPCA).

Results: The catPCA allowed the differentiation of four groups, three with urban characteristics (high urban, medium urban, impoverished urban), and a rural group. Stunting occurred at a higher rate in the impoverished urban group, and the occurrence of underweight children was higher in the rural group. The prevalence of excess weight varied in the range of $20-26 \%$. The latter value corresponded to children of the high urban group, who also did not show reduced muscle mass.

Conclusion: Children from San Rafael presented differences in nutritional condition and body composition associated with pronounced socio-environmental heterogeneity. Thus, we could observe a gradient from the "high urban" group, with better social, economic, and sanitation conditions and at the same time a more obesogenic environment to the "impoverished urban" and "rural" groups, whose vulnerability reflected a higher prevalence of child undernutrition and the association with excess weight and reduced muscle mass. Am. J. Hum. Biol. 28:796-803, $2016 . \quad \odot 2016$ Wiley Periodicals, Inc.

In recent years, the process of urbanization in Latin America has accelerated, due in part to the uncontrolled expansion of cities as caused by internal rural to urban migration, which has had both social and environmental impacts. In Argentina, migration and spatial redistribution rates have varied as a result of numerous historical events, with a concentrations of events in the second half of the last century (Pizzolitto, 2006; Velázquez and Gómez Lende, 2005). In 1960, the urban population rate was $73 \%$, rising to 82.6 and $89.4 \%$ in 1991 and 2001, respectively (CNPyV, 1991, 2001). Currently, approximately 9 out of 10 Argentinians live in urban areas, placing our country among those most urbanized in Latin America (World Bank, 2015).

The impetus for this rural-urban migration is mainly economic, due to the search for a better quality of life (Pizzolitto, 2006). However, in many cases, urban growth has been accompanied by poverty, overcrowding, and environmental degradation (León, 2007; Ruel et al., 2008). In addition, this process has caused remarkably rapid changes in dietary and lifestyle habits (Popkin, 2006), leading to a high incidence of malnutrition that includes both undernutrition and overweight/obesity. So, the prevalence of obesity and noncommunicable diseases such as diabetes and cardiovascular disease coexists with undernutrition and other poverty-related diseases in the same population.

Previous reports in peri-urban areas from different Argentinean cities have shown that inadequate socioeconomic conditions adversely affect child growth (Cesani et al., 2010; Oyhenart et al., 2013). The prevalence of undernutrition and intestinal parasitoses was higher in peri-urban as compared with urban and rural areas (Cesani et al., 2007; Zonta, 2010; Zonta et al., 2014). These inadequate conditions affected both nutritional status and body composition (Marrodán Serrano et al., 2007).

Considering the level of complexity of the above mentioned urban features, it is necessary to critically evaluate the classical criteria used to define them. Some authors have discussed the classification of urban and rural environments in terms of administrative boundaries, agglomerations (physical structure), size, and population density, or a combination of these criteria (Dufour and Piperata, 2004; Fotso, 2007). To avoid the use of the traditional urban-rural classification, in a study performed in General Alvear, province of Mendoza, Argentina, we used the categorical principal components analysis (catPCA)

Contract grant sponsor: UNLP 11/N679, ANPCyT PICT 01541 and CONICET PIP 02197

MG, MFC, GTN, and EEO analyzed the data and drafted, edited for intellectual content and provided critical comments on the manuscript. MG, GTN, and EEO designed the study, and directed implementation. MG, GTN, and EEO designed the data.

$\mathrm{MG}$, and GTN collected the data.

*Correspondence to: Mariela Garraza, IGEVET-Instituto de Genética Veterinaria "Ing. Fernando Noel Dulout" (UNLP-CONICET La Plata), Facultad de Ciencias Veterinarias, UNLP, La Plata, Argentina, Calle 60 , 118 s/n - B1901AAP, La Plata-Buenos Aires, Argentina. E-mail: mgarraza@igevet.gob.ar

Received 6 September 2015; Revision received 4 March 2016; Accepted 2 May 2016

DOI: $10.1002 /$ ajhb.22869

Published online 30 May 2016 in Wiley Online Library (wileyonlinelibrary.com). 
(Oyhenart et al., 2008). This model generates subpopulations as a function of their socio-environmental characteristics (income, parental education, access to public services, health care, and other parameters). By this means, nutritional status is seen exclusively within the context of the characteristics that define each subpopulation. The results obtained showed a marked urban heterogeneity regarding environmental quality, family socioeconomic level, and child nutritional status. Then, in 2009, using the same model, we performed a preliminary study in San Rafael, a neighboring city to General Alvear, and analyzed the prevalence of excess weight. We observed that overweight distribution was homogeneous and independent of family socio-economic conditions, whereas obesity was concentrated mainly in the rural area (Garraza et al., 2011). Therefore, following this conceptual framework, the aim of the present study was to analyze the nutritional status and body composition of children from San Rafael, Mendoza, avoiding urban and rural categorization by generating subpopulations as a function of their socio-environmental characteristics.

\section{SUBJECTS AND METHODS Study area}

The Department of San Rafael is located in the center of the Province of Mendoza ( $34^{\circ} 37^{\prime} \mathrm{S}$ and $68^{\circ} 20 \mathrm{~W}$ ), covering an area of $31235 \mathrm{~km}^{2}$. It is limited in the north by the Departments of San Carlos, Santa Rosa, and La Paz in the southeast by the Department of Malargüe, in the south by the province of La Pampa, in the east by the Department of General Alvear and the province of San Luis, and in the west by the Andes (Dirección de Estadística e Investigaciones Económicas, DEIE, 2011). The climate is warm and dry, with a mean annual temperature of $14.8^{\circ} \mathrm{C}$ and an annual precipitation rate of 250 $328 \mathrm{~mm}$.

The economy is mainly based on the agricultural industry of vine growing and processing, stone-fruit growing (plum, peach, and olive trees), vegetable growing (garlic, onion, tomato, squash, and sweet corn), and breeding of cows and goats (Instituto de Desarrollo Rural, IDR, 2007).

\section{Sample}

A cross-sectional study was performed in 3,596 children (1,776 boys and 1,820 girls; age range: 4.0-13.9 years) attending schools at San Rafael, Mendoza (Table 1). The sample selection was nonprobabilistic and largely determined by voluntary participation in the study. Children were included in the anthropometric study only after the respective parents or legal guardian gave written consent. No cases of chronic diseases or pathological conditions were present among the individuals surveyed.

The research protocols followed the principles outlined in the Helsinki Declaration and its subsequent modifications, as well as those dictated by Argentine National Law $\mathrm{N}^{\circ} 25.326$ on the privacy of personal data.

\section{Anthropometric analysis}

One of the authors (M.G.) performed assessments at the schools, following international standardized protocols (Lohman et al., 1988). The instruments were calibrated at the beginning of each session.

The following variables were recorded: age, obtained from identification cards or school records; body weight
TABLE 1. Sample composition

\begin{tabular}{lrrr}
\hline Age (years) & Male & Female & Total \\
\hline $4.0-4.9$ & 123 & 114 & 237 \\
$5.0-5.9$ & 208 & 167 & 375 \\
$6.0-6.9$ & 174 & 193 & 367 \\
$7.0-7.9$ & 202 & 209 & 411 \\
$8.0-8.9$ & 187 & 225 & 438 \\
$9.0-9.9$ & 211 & 227 & 443 \\
$10.0-10.9$ & 229 & 214 & 396 \\
$11.0-11.9$ & 196 & 200 & 370 \\
$12.0-12.9$ & 176 & 194 & 147 \\
$13.0-13.9$ & 70 & 77 & 3596 \\
Total & 1776 & 1820 & \\
\hline
\end{tabular}

(W, kg), measured on a digital scale (100 g accuracy) with the subjects lightly dressed and subtracting the weight of clothes; height $(\mathrm{H}, \mathrm{cm})$, using a portable vertical anthropometer (1 $\mathrm{mm}$ accuracy), upper arm circumference (UAC, $\mathrm{cm}$ ) measured with a flexible steel tape ( $1 \mathrm{~mm}$ accuracy), and tricep skinfold (TS) measured in millimeters with a Lange caliper (1 mm accuracy). Body mass index (BMI) was calculated as weight $(\mathrm{kg})$ divided by height squared $\left(\mathrm{m}^{2}\right)$.

Intra-observer variations were determined with the intra-class correlation coefficient (range, 0-1). Values greater than 0.75 were considered acceptable (Prieto et al., 1998).

Nutritional status was estimated with the NHANES III reference (Frisancho, 2008). The cut-off value was the fifth percentile to determine low weight-for-age (underweight), low height-for-age (stunting), and low weight-forheight (wasting). Individuals were classified as overweight or obese when their BMI was in the 85-95th percentile or above the 95th percentile, respectively (Frisancho, 2008). Then, we considered undernutrition (children with at least one of the following nutritional conditions: underweight, stunting, or wasting) and excess weight (children with overweight or obesity).

The Z-scores were calculated using the NHANES III reference to analyze body composition in children with undernutrition and excess weight. Total (TA), muscular (MA), and fat (FA) areas of the arm were estimated with the formulas proposed by Frisancho $(2008)$ : TA $=\left\{\left(\mathrm{UAC}^{2}\right) /\right.$ $(4 \times \pi)\} ; \mathrm{MA}=\{\mathrm{UAC}-(\mathrm{TS} \times \pi)\}^{2} /(4 \times \pi) ; \mathrm{FA}=(\mathrm{TA}-\mathrm{MA})$.

\section{Socio-environmental analysis}

We used a structured questionnaire filled out by the parents to evaluate several socio-environmental characteristics, and to measure housing variables with information regarding structural and physical amenities. These characteristics provided information about indoor housing conditions such as characteristics of housing construction, overcrowding, main source of drinking water, form of sewage disposal, fuel used for cooking and heating, as well as outdoor housing conditions, such as the degree of coverage and access to public services (pavement, electricity, and waste collection). To complement the information on the family socio-economic level, we asked about lodging or housing tenure, level of education and parental employment, medical coverage through explicit health insurance. We also evaluated supplementary income that included access to national or local programs from governmental agencies, nongovernmental organizations, or other entities used to benefit poor families by supplementing their 
TABLE 2. Eigenvectors from catPCA of socio-environmental variables

\begin{tabular}{|c|c|c|c|}
\hline Variable & Abbreviation & Dimension 1 & Dimension 2 \\
\hline Gas (piped) & $(\mathrm{GP})$ & 0.73 & -0.37 \\
\hline Bottled gas (cylinder) & (BG) & -0.68 & 0.39 \\
\hline Father's education & $(\mathrm{FE})$ & 0.61 & 0.24 \\
\hline Mother's education & (ME) & 0.64 & 0.20 \\
\hline Sewage system & (SS) & 0.59 & -0.31 \\
\hline Computer & (C) & 0.53 & 0.51 \\
\hline Waste collection & (WC) & 0.48 & -0.12 \\
\hline Internet & (I) & 0.48 & 0.37 \\
\hline Pavement & (P) & 0.47 & -0.22 \\
\hline Health Insurance & (HI) & 0.46 & 0.13 \\
\hline Piped water system & (PWS) & 0.42 & -0.14 \\
\hline Firewood & (F) & -0.42 & 0.36 \\
\hline Septic tank & (ST) & -0.35 & 0.33 \\
\hline Television & $(\mathrm{T})$ & 0.32 & 0.52 \\
\hline Car & (CA) & 0.31 & 0.63 \\
\hline Air-conditioning & (AC) & 0.30 & 0.31 \\
\hline Overcrowding & (OC) & -0.28 & -0.05 \\
\hline Animal husbandry & $(\mathrm{AH})$ & -0.28 & 0.27 \\
\hline Protected well & $(\mathrm{PW})$ & -0.24 & 0.18 \\
\hline Lodging Status & (LS) & -0.23 & -0.01 \\
\hline Orchad (agriculture) & (O) & -0.21 & 0.23 \\
\hline Electricity & (E) & 0.20 & 0.05 \\
\hline Nutritional support & (NS) & -0.16 & -0.03 \\
\hline Monetary support & (MS) & -0.08 & -0.15 \\
\hline
\end{tabular}

food budget (nutritional support) and/or by providing cash relief to the heads of households (monetary support). Animal husbandry and orchard agriculture were also considered. Other aspects taken into account were car ownership, internet access, computer access, and air conditioning (Oyhenart et al., 2008; Garraza, 2013).

The socio-environmental data were analyzed using the catPCA technique, which reduces the complexity of the set of observations related to each child, without losing information. In other words, it can transform a set of inter-correlated variables $(p)$ in another set $(q)$ of uncorrelated variables $(p \leq q)$ called principal components (PC). PC were obtained as linear combinations of the original variables and sorted according to the percentage of explained variance. The Cronbach's Alpha coefficient was used to determine the reliability of the test in terms of the number of items (or length of the test), and the proportion of total variance of the test due to the covariance between its parts (Ledesma et al., 2002). A Cronbach's Alpha greater than 0.7 was considered sufficient to ensure the reliability of the scale (Oviedo and CampoArias, 2005).

The catPCA allowed for the grouping of children according to their own socio-environmental characteristics of residence. The prevalence of nutritional status was calculated. To know the possible intergroup differences, the chi square test $\left(X^{2}\right)$ at a significance level of $P<0.05$ was applied. All statistical processing was carried out using the SPSS v 12 program.

\section{RESULTS}

\section{Socio-environmental conditions}

The first two dimensions (components) represented $26.07 \%$ of the total variance. The Cronbach's Alpha values were 0.83 and 0.62 for the first and the second axes, respectively.

Table 2 summarizes eigenvectors from catPCA. The most influential variables in the analysis were parental education and some physical amenities such as piped gas, bottled gas, and sewer system. Nutritional support and monetary support had the lowest eigenvectors.

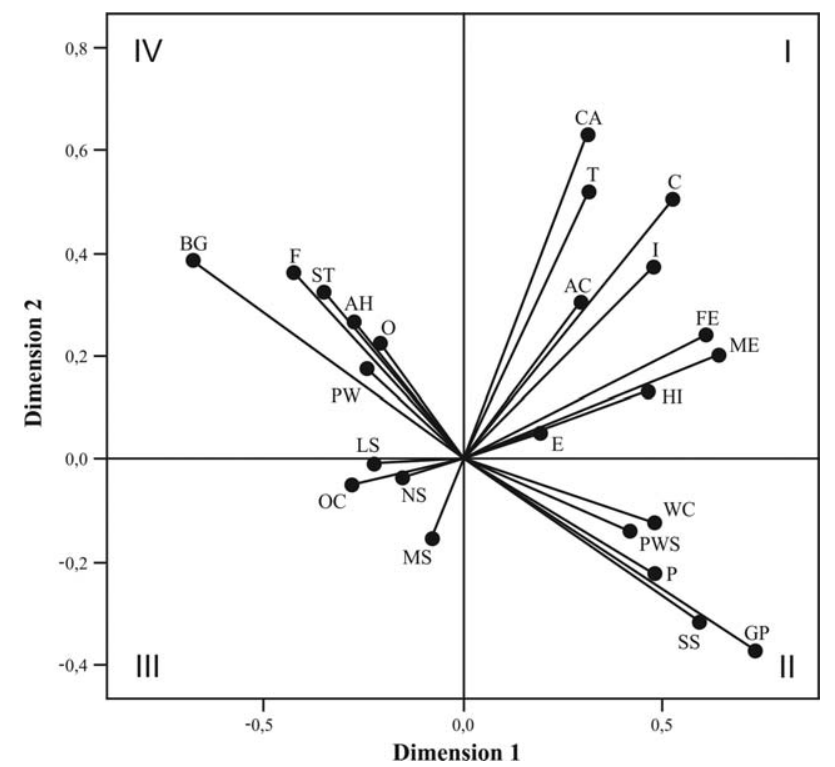

Fig. 1. Eigenvectors corresponding to socio-environmental characteristics. Group I (top right), Group II (lower right), Group III (lower left), and Group IV (top Left). Building material (BM), father and mother's work (FW, MW) are not visible in the figure because they are multiple nominal variables (nonlinear).

The two-dimensional representation of space allowed the differentiation of four groups (Fig. 1). Table 3 depicts the frequency of each variable (expressed as a percentage) per group.

Group I (dimension-1 positive, dimension-2 positive) ( $n=660$ children): Families had access to health insurance, electricity, television, internet, computers, cars, and air conditioning. Most parents were formally employed or self-employed workers, and had high education levels (high school, tertiary/university). They lived in their own houses, built with fired brick masonry.

Group II (dimension-1 positive, dimension-2 negative) ( $n=801$ children): Families lived in neighborhoods with great access to piped gas, sewage system, pavement, piped water system, and waste collection. Parent education was elementary or high school level and the majority had formal employment. Twenty-five percent of the families perceived monetary support and more than $50 \%$ had health insurance. Most families had houses constructed with fired brick masonry.

Group III (dimension-1 negative, dimension-2 negative) $(n=1084)$ : Families lived in deficient dwellings with limited public services. Some of these houses had no piped water or sewage system. This Group also had the highest percentage of overcrowding and the lowest parental education. Parental employment was mostly informal, and mothers were unemployed. More than $40 \%$ of these families received public assistance (nutritional and/or monetary support), and only $22.5 \%$ had health insurance.

Group IV (dimension-1 negative, dimension-2 positive) ( $n=1051)$ : families that practiced orchard agriculture and animal husbandry for personal consumption, used bottled gas and firewood for heating or cooking. Drinking water was obtained by piped water system or protected well, and sewage was removed by septic tank. This group had middle parental education levels (elementary and 
TABLE 3. Socio-environmental characteristics of the groups

\begin{tabular}{|c|c|c|c|c|c|c|}
\hline \multirow[b]{2}{*}{ Characteristics } & \multicolumn{3}{|c|}{ Percentage by group } & \multirow[b]{2}{*}{ IV } & \multirow[b]{2}{*}{$X^{2}$} & \multirow[b]{2}{*}{$P$ values } \\
\hline & I & II & III & & & \\
\hline \multicolumn{7}{|c|}{ Structural qualities and amenities } \\
\hline Building materials (BM) & & & & & 114.09 & $<0.01$ \\
\hline Low quality prefab & 2.15 & 2.87 & 4.72 & 3.08 & & \\
\hline Fired brick masonry & 89.70 & 85.75 & 72.42 & 80.30 & & \\
\hline Makeshift materials & 0.61 & 1.37 & 4.34 & 1.44 & & \\
\hline Other & 5.22 & 7.75 & 15.48 & 11.77 & & \\
\hline Overcrowding $(O C)$ & 12.75 & 14.57 & 40.11 & 34.28 & 242.76 & $<0.01$ \\
\hline \multicolumn{7}{|l|}{ Drinking water (main source) } \\
\hline Piped water system (PWS) & 96.36 & 97.00 & 78.59 & 61.75 & 527.47 & $<0.01$ \\
\hline Protected well (PW) & 2.27 & 0.62 & 4.77 & 15.80 & 215.98 & $<0.01$ \\
\hline \multicolumn{7}{|l|}{ Wastewater disposal } \\
\hline Sewage system (SS) & 25.87 & 49.81 & 4.86 & 1.23 & 912.02 & $<0.01$ \\
\hline Septic tank (ST) & 69.19 & 43.44 & 71.60 & 85.22 & 375.96 & $<0.01$ \\
\hline \multicolumn{7}{|l|}{ Fuel (cooking and heating) } \\
\hline Gas (piped) (GP) & 41.51 & 79.77 & 5.14 & 0.66 & 1820.21 & $<0.01$ \\
\hline Bottled gas (cylinder) (BG) & 56.51 & 17.72 & 88.77 & 97.23 & 1631.20 & $<0.01$ \\
\hline Firewood $(\mathrm{F})$ & 38.03 & 8.73 & 42.60 & 69.90 & 702.91 & $<0.01$ \\
\hline Pavement $(P)$ & 50.45 & 70.66 & 27.39 & 13.60 & 757.92 & $<0.01$ \\
\hline Electricity $(E)$ & 97.26 & 96.37 & 85.56 & 90.85 & 103.57 & $<0.01$ \\
\hline Waste Collection (WC) & 89.24 & 90.88 & 58.38 & 41.33 & 695.52 & $<0.01$ \\
\hline \multicolumn{7}{|l|}{ Socioeconomic status } \\
\hline Lodging Status (LS) & & & & & 290.33 & $<0.01$ \\
\hline House owner & 69.30 & 49.06 & 53.30 & 57.80 & & \\
\hline Lease Holder & 17.32 & 33.33 & 14.46 & 9.09 & & \\
\hline Free lodging & 12.76 & 15.98 & 29.86 & 30.52 & & \\
\hline \multicolumn{5}{|l|}{ Father's Education (FE) } & 1041.08 & $<0.01$ \\
\hline Elementary & 33.58 & 49.04 & 60.50 & 69.09 & & \\
\hline High school & 44.47 & 34.98 & 5.93 & 13.35 & & \\
\hline Tertiary/University & 19.17 & 5.19 & 0.30 & 0.59 & & \\
\hline \multicolumn{5}{|l|}{ Mother's Education (ME) } & 1105.14 & $<0.01$ \\
\hline Elementary & 31.69 & 45.77 & 72.11 & 72.15 & & \\
\hline High school & 36.90 & 36.68 & 7.64 & 13.82 & & \\
\hline Tertiary/University & 30.47 & 13.06 & 0.19 & 1.86 & & \\
\hline \multicolumn{5}{|l|}{ Father's Work (FW) } & 1124.43 & $<0.01$ \\
\hline Formal employed & 63.55 & 60.82 & 24.04 & 29.90 & & \\
\hline Laborer & 2.29 & 5.18 & 11.14 & 20.67 & & \\
\hline Informal worker & 5.20 & 8.09 & 36.85 & 34.36 & & \\
\hline Self-employed worker & 23.76 & 14.41 & 1.95 & 6.79 & & \\
\hline Unemployed & 1.37 & 2.90 & 5.96 & 3.10 & & \\
\hline Retired & 0.91 & 1.01 & 1.85 & 1.94 & & \\
\hline \multicolumn{7}{|l|}{ Mother's Work (MW) } \\
\hline Formal employer & 41.18 & 41.75 & 14.20 & 8.34 & 1278.71 & $<0.01$ \\
\hline Laborer & 0.30 & 0.62 & 2.06 & 2.58 & & \\
\hline Informal worker & 1.67 & 2.50 & 14.11 & 7.47 & & \\
\hline Autonomous worker & 9.57 & 8.37 & 1.41 & 3.74 & & \\
\hline Unemployed & 4.55 & 20.75 & 30.76 & 17.25 & & \\
\hline Housewife & 41.94 & 11.62 & 18.06 & 52.44 & & \\
\hline Retired & 0.45 & 1.00 & 5.45 & 6.42 & & \\
\hline Health Insurance (HI) & 78.80 & 63.17 & 22.49 & 34.03 & 666.47 & $<0.01$ \\
\hline Public assistance & & & & & & \\
\hline Monetary support (MS) & 15.60 & 25.71 & 31.60 & 19.40 & 73.32 & $<0.01$ \\
\hline Nutritional support (NS) & 1.50 & 3.30 & 11.05 & 9.53 & 82.55 & $<0.01$ \\
\hline Farming practice & & & & & & \\
\hline Orchad (agriculture) $(\mathrm{O})$ & 5.30 & 1.37 & 4.31 & 20.40 & 274.69 & $<0.01$ \\
\hline Animal husbandry $(\mathrm{AH})$ & 8.48 & 1.87 & 6.83 & 34.73 & 527.73 & $<0.01$ \\
\hline Other & & & & & & \\
\hline Internet (I) & 29.23 & 1.01 & 0.00 & 0.00 & 550.98 & $<0.01$ \\
\hline Television (T) & 77.44 & 38.64 & 10.35 & 9.30 & 578.91 & $<0.01$ \\
\hline Computer $(\mathrm{C})$ & 74.96 & 25.42 & 1.29 & 10.96 & 1068.31 & $<0.01$ \\
\hline Air conditioning (AC) & 13.54 & 0.34 & 0.10 & 0.00 & 218.98 & $<0.01$ \\
\hline Car (CA) & 84.38 & 27.55 & 3.09 & 49.00 & 877.82 & $<0.01$ \\
\hline
\end{tabular}

high school). Parental employment was mostly informal and mothers were housewives.

All socio-environmental variables differed significantly among groups (Table 3).

\section{Nutritional status}

The highest prevalence of undernutrition was found in Group III (11.2\%) followed by Group IV (10.8\%), showing a significant difference with Groups I (6.1\%) and II (5.2\%). Similar results were observed when stunting was analyzed separately (GIII: $10.5 \%$, GIV: $9.9 \%$, GI: $5.2 \%$, and GII: $4.5 \%$ ). Again, Groups III and IV differed significantly compared with Groups I and II. Underweight was higher in Group IV (2.4\%), followed by GIII (1.5\%), GII (1.3\%), and GI $(0.9 \%)$, showing a significant difference only between GI and GIV. Finally, wasting values were very low (GI: $0.5 \%$, GII: $0.5 \%$, GIII: $0.4 \%$, GIV: $0.3 \%$ ), and 
nonsignificant differences were recorded among groups (Table 4).

The prevalence of excess weight was higher in Group I $(26.2 \%)$, and differed significantly from that in Groups II (20.6\%), III (20.9\%), and IV (20.9\%). When overweight and obesity were analyzed separately, differences were not significant (Overweight: GI, 12.4\%; GII, 11.4\%; GIII,

TABLE 4. Prevalence (\%) of nutritional status indicators by group

\begin{tabular}{|c|c|c|c|c|c|c|}
\hline \multirow[b]{2}{*}{ Indicator } & \multicolumn{3}{|c|}{ Group } & \multirow[b]{2}{*}{ IV } & \multirow[b]{2}{*}{ Comparison } & \multirow[b]{2}{*}{$P$ value } \\
\hline & I & II & III & & & \\
\hline \multirow[t]{4}{*}{ Undernutrition } & 6.06 & 5.24 & 11.16 & 10.75 & I-III & $<0.01$ \\
\hline & & & & & I-IV & $<0.01$ \\
\hline & & & & & II-III & $<0.01$ \\
\hline & & & & & II-IV & $<0.01$ \\
\hline Underweight & 0.91 & 1.25 & 1.48 & 2.38 & I-IV & $<0.05$ \\
\hline \multirow[t]{4}{*}{ Stunting } & 5.15 & 4.49 & 10.52 & 9.90 & I-III & $<0.01$ \\
\hline & & & & & I-IV & $<0.01$ \\
\hline & & & & & II-III & $<0.01$ \\
\hline & & & & & II-IV & $<0.01$ \\
\hline Wasting & 0.50 & 0.50 & 0.40 & 0.30 & All & $>0.05$ \\
\hline \multirow[t]{3}{*}{ Excess of weight } & 26.21 & 20.6 & 20.94 & 20.93 & I-II & $<0.01$ \\
\hline & & & & & I-III & $<0.01$ \\
\hline & & & & & I-IV & $<0.01$ \\
\hline Overweight & 12.42 & 11.36 & 9.96 & 9.71 & All & $>0.05$ \\
\hline Obesity & 13.79 & 9.24 & 10.98 & 11.23 & All & $>0.05$ \\
\hline
\end{tabular}

Group I

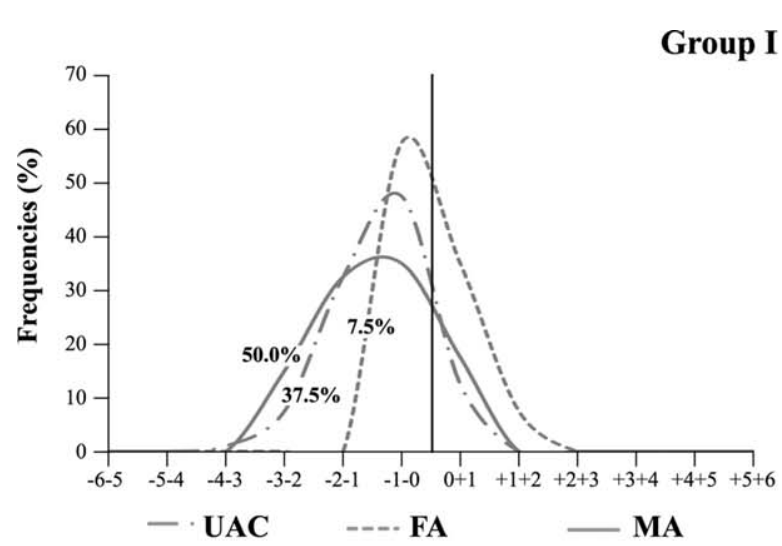

Group III

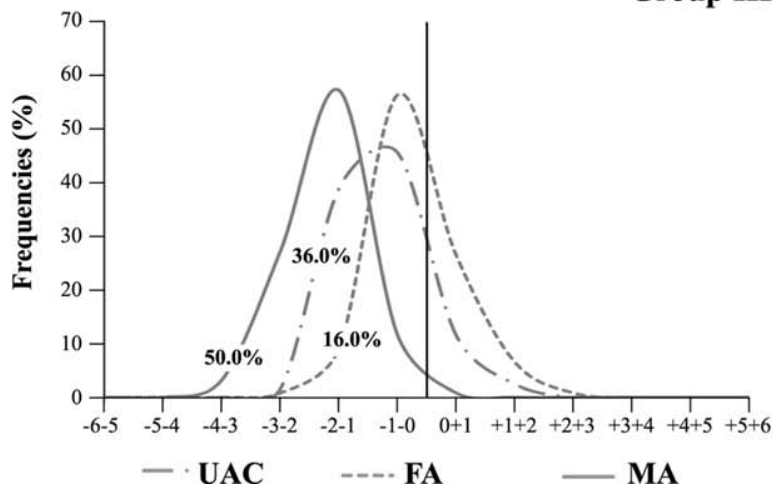

10.0\%; GIV, 9.7\%; Obesity: GI, 13.8\%; GII, 9.2\%; GIII, 11.1\%; GIV, 11.2\%) (Table 4).

Figures 2 and 3 show the Z-score distributions and skewed percentages of UAC, MA, and FA. In undernourished children from all groups, the distributions of the three variables were skewed to the left, with the MA area the most affected (Fig. 2). Conversely, in the population of children with excess weight, the distributions were skewed to the right, except for the MA area in Groups II, III, and IV (Fig. 3).

\section{DISCUSSION}

The study population showed internal differences in both environmental quality conditions and socio-economic level, as already reported for General Alvear and San Rafael, Mendoza (Garraza et al., 2011; Oyhenart et al., 2008). The use of a classification different from the traditional one that establishes an urban-rural dichotomy permitted us to differentiate four groups; three of them associated with urban socio-environmental characteristics, and the fourth group with the rural environment. This is in agreement with the report by Ruel (2000) about the existence of heterogeneity in the urban areas.

Although the three urban groups had access to the basic public services, differences in parental education and occupation, and access to consumer goods and health

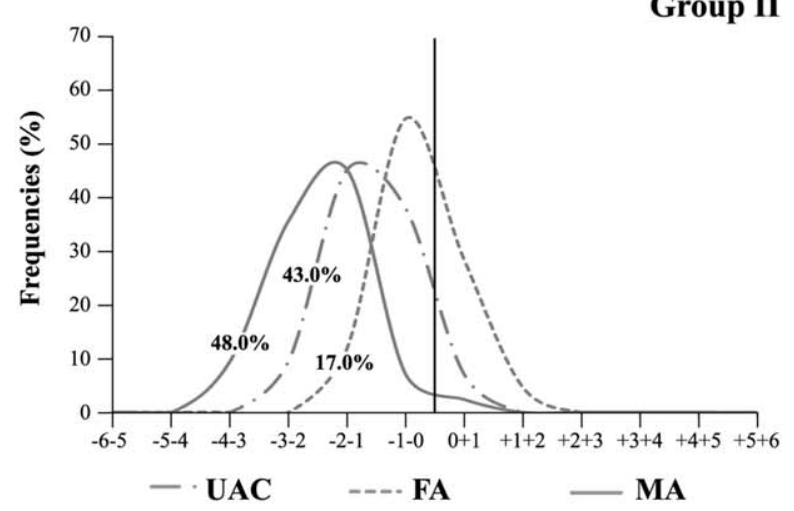

Fig. 2. Z-score distributions of upper arm circumference (UAC), muscular (MA), and fat arm (FA) areas in children with undernutrition. Values correspond to the percentage of skewed distributions for each variable. 

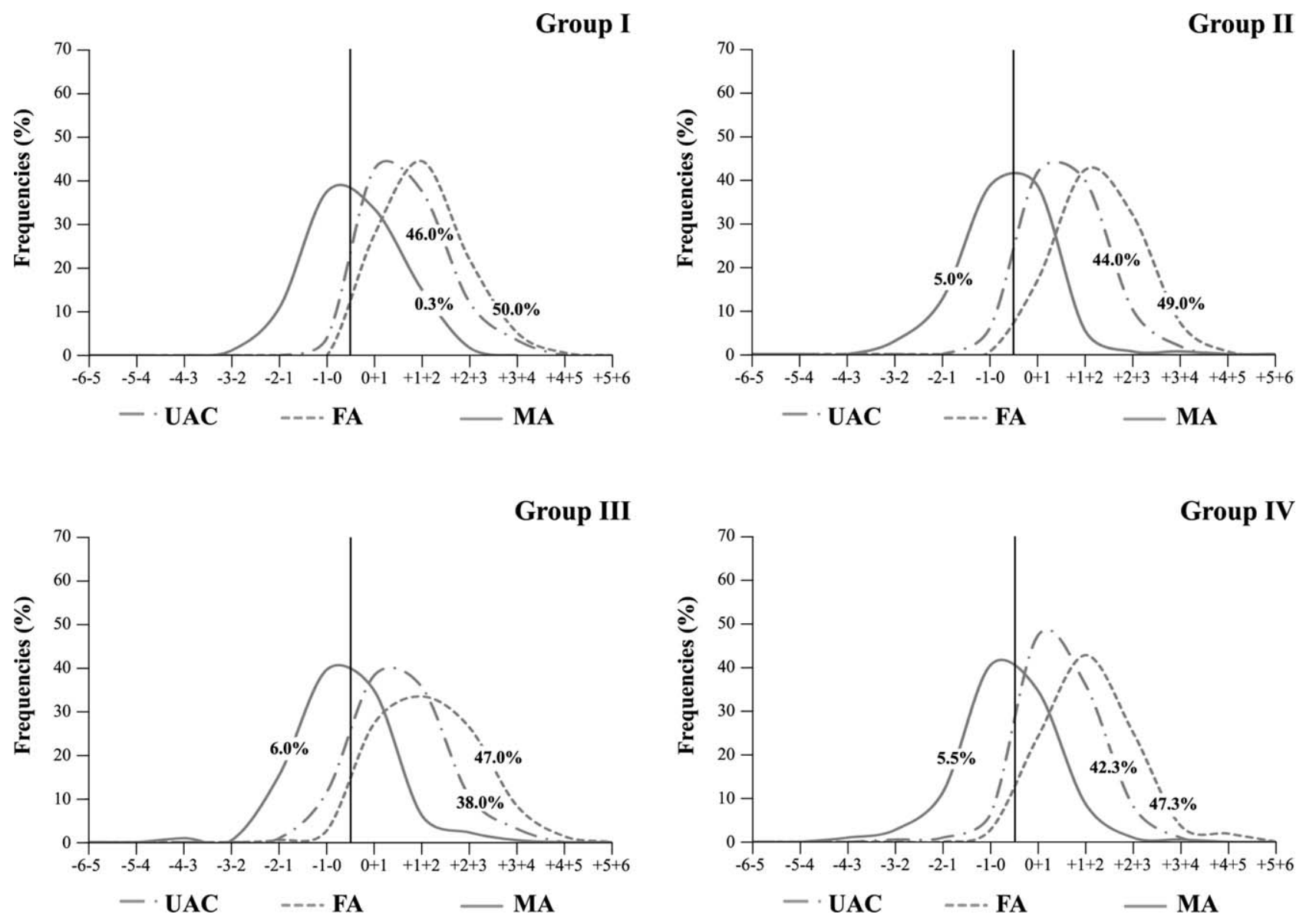

Fig. 3. Z-score distributions of upper arm circumference (UAC), muscular (MA), and fat arm (FA) areas in children with excess weight. Values correspond to the percentage of skewed distributions for each variable.

coverage, enabled us to group them into high urban (I), medium urban (II), and impoverished urban (III) groups. Group I (high urban) exhibited the most favorable socioenvironmental conditions of San Rafael, namely, ownership of good-quality housing, availability of public services, high educational level, formal employment, and health coverage of the parents, as well as the lowest and highest prevalence of undernutrition and excess weight, respectively. Indeed, the purchasing power of the families and the education level of parents allowed better food access, probably contributing to the development of an obesogenic environment. This situation falls within the global nutrition transition, mainly characterized by the consumption of diets high in saturated fats, sugar, and refined foods but low in fiber, and a sedentary lifestyle (Popkin and Gordon-Larsen, 2004). In this sense, families from this group had the highest rate of access to consumption goods and comfort. The frequent use of different means of transport (bus, car, motorcycle) and recreational activities (watching TV, using a computer, and playing video games) lead to more sedentary lifestyles (Popkin, 2006; Van der Horst et al., 2007).

In Group II (medium urban), the family socioenvironmental situation was less favorable compared with Group I. However, the availability of public services was greater, probably because they mostly lived in urbanized neighborhoods built in the last years by the Mendoza Provincial Housing Institute. In general, people had access to this type of household through special loans for formal employees grouped according to their work activity (i.e., teacher, policeman, bank clerk). The nutritional status of these children was similar to that of children in Group I, but the prevalence of undernutrition and excess weight was lower.

According to Clichevsky (2002), the environmental conditions of urban areas vary depending on the socioeconomic level of the population and subsequent effects on populations. In this sense, social inequality can be reflected in a city's production and maintenance, i.e., cities with access to services and lack of environmental degradation, and others without access to services or equipment and a degraded environment. The latter description corresponds to the impoverished urban Group III, which includes children from low-income families living in lowcost housing units (adobe, wood, or sheet walls), scarce access to sanitary services, and overcrowded conditions. In this context, $10.5 \%$ of children presented chronic undernutrition, reflecting a history of structural vulnerability. These results agree with those reported by the World Health Organization (WHO, 2004) concerning the 
fact that poor sanitation, housing conditions, and family socio-economic level are some of the environmental factors that contribute to growth retardation.

Finally, the rural group included children who lived in houses that were lent, hired, or belonged to the land's owner, and who had less access to public services. As a contribution to their household economies, families had their own orchard agriculture and raised animals for selfconsumption. According to the Food and Agriculture Organization, orchard agriculture and animal husbandry are common in peri-urban and rural areas in Latin America; these families' productive undertakings provide them with an income and make them self-sufficient in terms of food, fuel, and other materials (Landon-Lane, 2004). It is clear, however, that while these practices are historically associated with the family lifestyle and rural economy of San Rafael, they were not sufficient to mitigate the nutritional deficiencies of children from this group, whose prevalence of chronic undernutrition was similar to that reported for the urban impoverished group. Children further presented the highest prevalence of low weight-forage, indicating that food deficiencies are still present. Menon et al. (2000), using information from the Demographic and Health Survey performed in 11 countries, reported that intra-urban differences in chronic infant malnutrition are higher than intra-rural ones, but similar between poor urban and rural populations. Thus, beyond the global tendency toward a decrease in the prevalence of chronic growth retardation (de Onis et al., 2012), low height remains an unresolved nutritional concern.

The analysis of body composition revealed some aspects that would have been masked if only BMI or weight-forheight, weight-for-age, or height-for-age ratios had been considered, thus revealing the etiology of malnutrition (Moreno-Romero and Marrodán Serrano, 2009). Body composition of children at both ends of malnutrition was modified; whereas a high proportion of undernourished children had decreased muscular and adipose mass, overweight and obese children presented increased adipose tissue. However, excess adiposity associated with decreased muscular mass was present in all groups, excepting the high urban one. This may be associated with the consumption of low-protein and high-calorie diets. Difficulties in the access to adequate food would predispose children living in less favorable environments to have weight excess with reduced muscle mass (Adjemian et al., 2007; Oyhenart et al., 2007).

\section{CONCLUSION}

Children from San Rafael presented differences in nutritional condition and body composition associated with a pronounced socio-environmental heterogeneity. Thus, we could observe a gradient from the "high urban" group, with better social, economic, and sanitation conditions and at the same time a more obesogenic environment, up to the "impoverished urban" and "rural" groups, whose vulnerability reflected in higher prevalence of child undernutrition, and correlation with excess weight and reduced muscle mass.

\section{ACKNOWLEDGMENTS}

The authors are grateful to María Eugenia Luna, Adriana Di Maggio, Lucia Featherston, María Cristina Muñe and the local authorities and educational staff of the Department of San Rafael, Mendoza for their assistance and collaboration.

\section{LITERATURE CITED}

Adjemian D, Bustos P, Amigo H. 2007. Nivel socioeconómico y estado nutricional: un estudio en escolares. ALAN 57:125-129.

Cesani MF, Luis MA, Torres MF, Castro LE, Quintero FA, Luna ME, Bergel ML, Oyhenart EE. 2010. Sobrepeso y obesidad en escolares de Brandsen en relación a las condiciones socioambientales de residencia. Arch Argent Pediatr 108(4):294-302.

Cesani MF, Zonta ML, Castro L, Torres MF, Forte LM, Orden AB, Quintero FA, Luis MA. Sicre ML, Navone GT, Gamboa MI, Oyhenart EE. 2007. Estado nutricional y parasitosis intestinales en niños residentes de zonas urbana, periurbana y rural del partido de Brandsen (Buenos Aires, Argentina). Rev Arg Antrop Biol 9(2):105-121.

Clichevsky N. 2002. Tierra vacante en ciudades latinoamericanas. Cambridge, MA: Lincoln Institute of Land Policy.

CNPyV. 1991. Censo Nacional de población, hogares y vivienda. Instituto Nacional de Estadística y Censos (INDEC). Ministerio de Economía de la Nación. Buenos Aires. Argentina.

CNPyV. 2001. Censo Nacional de población, hogares y vivienda. Instituto Nacional de Estadística y Censos (INDEC). Ministerio de Economía de la Nación. Buenos Aires. Argentina. Available at: http://www.indec.gov. ar

de Onis M, Blössner M, Borghi E. 2012. Prevalence and trends of stunting among pre-school children, 1990-2020. Public Health Nutr 15(1):142148

Dirección de Estadística e Investigaciones Económicas (DEIE). 2011. Ministerio de Agroindustria y Tecnología Gobierno de Mendoza. Publicaciones Municipales. San Rafael. Available at: http://www.deie.mendoza. gov.ar/publicaciones/

Dufour DL, Piperata BA. 2004. Rural-to-urban migration in Latin America: an update and thoughts on the model. Am J Hum Biol 16(4):395404.

Fotso JC. 2007. Urban-rural differentials in child malnutrition: trends and socioeconomic correlates in sub-Saharan Africa. Health Place 13: 205-223.

Frisancho AR. 2008. Anthropometric standards. An interactive nutritional reference of body size and body composition for children and adults. Ann Arbor, MI: University of Michigan Press.

Garraza M. 2013. Crecimiento, estado nutricional y enteroparasitosis en niños urbanos y rurales del departamento de San Rafael, Mendoza. PhD Thesis. Facultad de Ciencias Naturales y Museo. Universidad Nacional de La Plata. Argentina.

Garraza M, Sugrañes N, Navone GT, Oyhenart EE. 2011. Sobrepeso y obesidad en relación a condiciones socio-ambientales de niños residentes en San Rafael, Mendoza. Rev Arg Antrop Biol 13(1):19-28.

Instituto de Desarrollo Rural (IDR). 2007. Superficie cultivada con hortalizas en Mendoza. Temporada 2006-07. Available at: http://www.idr.org.ar

Landon-Lane C. 2004. Livelihood grow in gardens. Diversifying rura incomes through home gardens. Agricultural support systems division. Roma: Food and Agriculture Organization of the United Nations.

Ledesma R, Molina Ibañez G, Valero Mora P. 2002. Análisis de consistencia interna mediante Alfa de Cronbach: un programa basado en gráficos dinámicos. Psico-USF 7:143-152.

León C. 2007. Estudio descriptivo, comparativo y relacional del desarrollo infantil integral en una muestra de niños y niñas de diferentes edades, niveles socioeconómicos y regiones de Venezuela. Orbis. Revista Científica Ciencias Humanas 3(7):64-124.

Lohman TG, Roche AF, Martorell R. 1988. Anthropometric standardization reference manual. Champaign, IL: Human Kinetics Books.

Marrodán Serrano MD, Santos-Beneit MG, Mesa Santurino MS, Cabañas Armesilla MD, González-Montero de Espinosa M, Pacheco del Cerro JL. 2007. Técnicas analíticas en el estudio de la composición corporal. Antropometría frente a sistemas de bioimpedancia bipolar y tetrapolar. Nutr Clín Diet Hosp 1:11-19.

Menon P, Ruel M, Morris S. 2000. Socio-economic differentials in child stunting: results from 11 DHS data sets. Food Nutr Bull 21:282-289.

Moreno-Romero S, Marrodán Serrano MD. 2009. Evaluación nutricional de escolares Hausa de Batata (Sur de Niger). Observatorio Medioambiental 12:155-165.

Oviedo HC, Campo-Arias A. 2005. Aproximación al uso del coeficiente alfa de Cronbach; an approach to the use of Cronbach's Alfa. Rev colomb psiquiatr 34(4):572-580

Oyhenart EE, Castro LE, Forte LM, Sicre ML, Quintero FA, Luis MA Torres MF, Luna ME, Cesani MF, Orden AB. 2008. Socioenviromental conditions and nutritional status in urban and rural schoolchildren. Am J Hum Biol 20(4):399-405. 
Oyhenart EE, Garraza M, Bergel ML, Torres MF, Castro LE, Luis MA, Forte LM, Gamboa MI, Zonta ML, Cesani MF, Quintero FA, Luna ME, Navone GT. 2013. Caracterización del estado nutricional, enteroparasitosis y condiciones socio-ambientales de la población infanto-juvenil de Partido de La Plata. Rev Arg Antrop Biol 15(1):47-60.

Oyhenart EE, Torres MF, Quintero FA, Luis MA, Cesani MF, Zucchi M, Orden AB. 2007. Estado nutricional y composición corporal de niños pobres residentes en barrios periféricos de La Plata, Argentina. Rev Panam Salud Pública 22(3):194-201.

Pizzolitto G. 2006. Distribución de la población y migraciones internas en Argentina: sus determinantes individuales y regionales. $\mathrm{PhD}$ Thesis Facultad de Ciencias Económicas. Universidad Nacional de La Plata. Argentina.

Popkin BM. 2006. Global nutrition dynamics: the world is shifting rapidly toward a diet linked with noncommunicable diseases. Am J Clin Nutr 84:289-298.

Popkin BM, Gordon-Larsen P. 2004. The nutrition transition: worldwide obesity dynamics and their determinants. Int $\mathrm{J}$ Obes 28 : S2-S9.

Prieto L, Lamarca R, Casado A. 1998. La evaluación de la fiabilidad en las observaciones clínicas: el coeficiente de correlación intraclase. Med Clín (Barc) 110(4):142-145.

Ruel MT. 2000. Urbanization in Latin America: constraints and opportunities for child feeding and care. Food Nutr Bull 21(1):12-24.
Ruel MT, Garrett J, Haddad L. 2008. Rapid urbanization and the chal lenges of obtaining food and nutrition security. In: Semba RD, Bloem MW, editors. Nutrition and health series: nutrition and health in developing countries. Totowa, NJ: Humana Press. p 639-656

Van der Horst K, Paw MJ, Twisk JW, Van Mechelen W. 2007. A brief review on correlates of physical activity and sedentariness in youth. Med Sci Sports Exerc 39:1241-1250.

Velázquez GA, Gómez Lende S. 2005. Dinámica migratoria: coyuntura y estructura en la Argentina de fines del XX. Amérique Latine Histoire et Mémoire. Les Cahiers LHIM. Available at: http://alhim.revues.org/432

World Bank. 2015. Población urbana. Indicadores del desarrollo mundial Available at: http://datos.bancomundial.org/indicador/SP.URB.TOTL. IN.ZS.

World Health Organization (WHO). 2004. Stunting: main nutrition-related problem in WHO European Region. New WHO/UNICEF guidelines issued. Available at: http://www.euro.who.int/mediacentre/PR/2000/20010909_17

Zonta ML. 2010. Crecimiento, estado nutricional y enteroparasitosis en poblaciones aborígenes y cosmopolitas: Los Mbýa-Guaraní en el Valle del arroyo de Cuña Pirú y poblaciones aledañas (Misiones). PhD Thesis. Facultad de Ciencias Naturales y Museo. Universidad Nacional de La Plata. Argentina.

Zonta ML, Oyhenart EE, Navone GT. 2014. Socio-environmental variables associated with malnutrition and intestinal parasitoses in the child population of Misiones, Argentina. Am J Hum Biol 26:609-616. 